\section{角 Heighten Science \\ P U B L I C A T I O N S Corporation ISSN \\ 2577-1469}

Editorial

\title{
Stemness of Mesenchymal Stem Cells
} Tong Ming Liu*

Cancer Stem Cell Group, Genome Institute of Singapore, 60 Biopolis Street, 137682, Singapore

\begin{abstract}
*Address for Correspondence: Tong Ming Liu, $\mathrm{PhD}$, Cancer Stem Cell Group, Genome Institute of Singapore, 138672, Singapore, Tel: 65 68088229; Fax: 65 6808-8308; Email: dbsliutm@yahoo.com
\end{abstract}

Submitted: 22 December 2017 Approved: 28 December 2017 Published: 29 December 2017

Copyright: @2017 Liu TM. This is an open access article distributed under the Creative Commons Attribution License, which permits unrestricted use, distribution, and reproduction in any medium, provided the original work is properly cited

Check for updates
Mesenchymal stem cells (MSCs) are multipotent adult stem cells that can self-renew and differentiate into a variety of cell types including chondrocytes, osteocytes and adipocytes. MSCs reside in bone marrow, adipose tissues, cord blood, peripheral blood, placenta, Wharton's jelly, fetal liver and lung among others. MSCs represent one of the most promising stem cells for regenerative medicine due to their multipotency, immunoprivileged properties and easy expansion in vitro. So far, MSCs are already in various phases of clinical application [1-4]. Their most immediate use is in the orthopedic context due to the clear demonstration of their ability to differentiate into bone and cartilage [5-8]. It has been 5 decades since Friedenstein et al described clonal and plastic adherent stromal cells from bone marrow in the 1960s $[9,10]$. Although there are a handful of genes suggesting possible MSC stemness markers, the molecular basis underlying MSC stemness, especially the key transcription factor to MSC stemness, is still poorly understood.

There are several reasons for poor understanding of MSC stemness. First of all, the heterogeneity of MSCs greatly hamper in-depth MSC study. Variations exist among MSCs from different sources and culture conditions, even fast and slow growing CFUderived MSCs from the same patient also display differences [11,12]. So far, the factors that affect the heterogeneity of the MSC population is still largely unknown. Secondly, the limited lifespan of MSCs increases the difficulty to study MSCs, especially in case of large number of cells needed. Like other adult stem cells, MSCs undergo the replicative senescence after only a finite number of times in culture. At around passage 10, MSCs demonstrate morphological abnormalities, enlargement, attenuated expression of specific surface markers, and ultimately proliferation arrest $[13,14]$. In the meanwhile, MSCs reduce differentiation potential during prolonged in vitro culture [15]. The limited lifespan of MSCs also greatly compromises the therapeutic application of human MSCs due to limitation in cell number. Thirdly, little is known about MSC niche. Stem cell niche is a specific microenvironment, in which stem cells are able to selfrenew and maintain the undifferentiated state. So far, the MSC niche remains poorly understood.

Stem cell niche provides a milieu that prolongs cellular lifespan and maintains the undifferentiated state of stem cells. Mimicking endogeneous niche of MSCs is able to delay the cell aging and maintain MSC stemness, including hypoxia [16-18], coating with extra-cellular matrix (ECM) [19,20], and 3D culture [21,22] among others. Hypoxic environment has been suggested as physiologic niche to maintain stemness of stem cells. MSCs resides in niche characterized by hypoxic condition. Culture of MSCs under hypoxia enhanced proliferation and preserved the expression of stemnessrelated genes $[16,18]$. Changed gene expression profile of MSCs by hypoxia included differentiation, extracellular matrix, intermediate filament, metabolic gene, antioxidant genes and striated muscle genes [17]. In addition, extracelluar matrix (ECM) also plays important role in the stem cell niche. It was shown that hyaluronan (HA) prolonged the lifespan and prevented the cellular aging of murine adipose-derived MSCs [19]. MSCs expanded in flasks coating with ECM exhibited higher proliferation, formed more and larger sized cell colonies with smaller and more compactly arranged cells, 
and had greater differentiation potential [20]. 3D culture of MSCs on under spheroids or nanoculture plates, closer to in vivo niche of MSCs, delayed replicative senescence and enhanced the differentiation potential [21,22]. In addition, expansion of MSCs in medium containing FGF-2 appeared to promote proliferation and inhibit cellular senescence through a PI3K/AKT-MDM2 pathway [23]. Even blockage of endogenous glucocorticoids using RU486 significantly increase the proliferation and osteogenic differentiation of human MSCs [24].

Although efforts have been made for past 5 decades, little is known about the molecular basis underlying MSC stemness. So far, no one key transcription factor to MSCs like pluripotent genes Oct4, Nanog and Sox2 to ES has been identified, deprivation of which leads to the complete loss of MSC identity. To decipher the signature genes of MSCs, by comparing genes expression profile before and after tri-lineage differentiation, a list of highly expressed genes in undifferentiated MSCs were identified, including 9 transcription factors. However, individual knockdown only partially decrease proliferation or differentiation of MSCs [25]. NRF2 was identified as potential marker by analyzing gene expression. Knockdown of NRF2 decreased osteogenesis whereas overexpression of NRF2 increased the proliferation and reduced the rate of apoptosis of MSCs [26]. In addition, overexpression of cell surface protein CD49f (integrin subunit $\alpha 6$ ) modulated the proliferation and differentiation potentials of MSCs through activating PI3K/AKT and suppressing p53 expression [27]. Epigenetic modification also controls MSC function. BCL-6 co-repressor (BCOR) interacts with BCL-6 to repress AP2alpha, which is key factor that enhances osteo-dentinogenic capacity of MSCs. BCOR mutation results in abnormal activation of AP-2alpha, which leads to oculo-facio-cardio-dental (OFCD) syndrome characterized by canine teeth with extremely long roots, congenital cataracts, craniofacial defects and congenital heart disease. Further analysis showed that BCOR mutation activated silenced target genes by increasing histone H3K4 and H3K36 methylation in MSCs [28].

Although these studies expand our understanding towards MSCs, it is still not clear that these genes regulate MSC stemness or only differentiation. So far, the understanding towards MSC stemness is still the tip of the iceberg. To make better use of MSCs for regenerative medicine, more efforts are needed to decipher the molecular basis of MSCs, especially key transcription factors to MSCs.

\section{References}

1. Horwitz EM, Gordon PL, Koo WK, Marx JC, Neel MD, et al. Isolated allogeneic bone marrow-derived mesenchymal cells engraft and stimulate growth in children with osteogenesis imperfecta: Implications for cell therapy of bone. Proc Natl Acad Sci USA. 2002; 99: 8932-8937. Ref.: https://goo.gl/cRDDTN

2. Arinzeh TL, Peter SJ, Archambault MP, van den Bos C, Gordon S, et al. Allogeneic mesenchymal stem cells regenerate bone in a critical-sized canine segmental defect. J Bone Joint Surg Am. 2003; 85-A 1927-1935. Ref.: https://goo.gl/GgdNCY

3. Shi M, Liu Z, Wang Y, Xu R, Sun Y, et al. A Pilot Study of Mesenchymal Stem Cell Therapy for Acute Liver Allograft Rejection. Stem Cells Transl Med. 2017; 6: 2053-2061. Ref.: https://goo.gl/6quN8j

4. Introna M, Lucchini G, Dander E, Galimberti S, Rovelli A, et al. Treatment of graft versus host disease with mesenchymal stromal cells: a phase I study on 40 adult and pediatric patients. Biol Blood Marrow Transplant. 2014; 20: 375-381. Ref.: https://goo.gl/Akoyyn

5. Pittenger MF, Mackay AM, Beck SC, Jaiswal RK, Douglas R, et al. Multilineage potential of adult human mesenchymal stem cells. Science. 1999; 284: 143-147. Ref.: https://goo.gl/6zRMCm

6. Pountos I, Jones E, Tzioupis C, McGonagle D, Giannoudis PV. Growing bone and cartilage: The role of mesenchymal stem cells. J Bone Joint Surg Br. 2006; 88: 421-426. Ref.: https://goo.gl/3Hw8fw

7. Liu TM, Guo XM, Tan HS, Hui JH, Lim B, et al. Zinc-finger protein 145 , acting as an upstream regulator of SOX9, improves the differentiation potential of human mesenchymal stem cells for cartilage regeneration and repair. Arthritis Rheum. 2011; 63: 2711-2720. Ref.: https://goo.gl/5qNPH9

8. Liu TM, Martina M, Hutmacher DW, Hui JH, Lee EH, et al. Identification of common pathways mediating differentiation of bone marrow- and adipose tissue-derived human mesenchymal stem cells into three mesenchymal lineages. Stem Cells. 2007; 25: 750-760. Ref.: https://goo.gl/Nb8CWq 
9. Friedenstein AJ, Piatetzky-Shapiro II, Petrakova KV. Osteogenesis in transplants of bone marrow cells. J Embryol Exp Morphol. 1966; 16: 381-390. Ref.: https://goo.gl/MSYA4t

10. Friedenstein AJ, Petrakova KV, Kurolesova AI, Frolova GP. Heterotopic of bone marrow. Analysis of precursor cells for osteogenic and hematopoietic tissues. Transplantation. 1968; 2: 230-247. Ref.: https://goo.gl/yDxPdy

11. Mareddy S, Dhaliwal N, Crawford R, Xiao Y. Stem cell-related gene expression in clonal populations of mesenchymal stromal cells from bone marrow. Tissue Eng Part A. 2010; 16: 749-758. Ref.: https://goo.gl/FxccCy

12. Menicanin D, Bartold PM, Zannettino AC, Gronthos S. Identification of a common gene expression signature associated with immature clonal mesenchymal cell populations derived from bone marrow and dental tissues. Stem Cells Dev. 2010; 19: 1501-1510. Ref.: https://goo.gl/m4BvE6

13. Wagner W, Horn P, Castoldi M, Diehlmann A, Bork S, et al. Replicative senescence of mesenchyma stem cells: a continuous and organized process. PLoS One; 2008: 3: 2213. Ref.: https://goo.gl/LyyMg9

14. Liu TM, Ng WM, Tan HS, Vinitha D, Yang Z, et al. Molecular basis of immortalization of human mesenchymal stem cells by combination of p53 knockdown and human telomerase reverse transcriptase overexpression. Stem Cells Dev. 2013; 22: 268-278. Ref.: https://goo.gl/XdGNWm

15. Baxter MA, Wynn RF, Jowitt SN, Wraith JE, Fairbairn LJ, et al. Study of telomere length reveals rapid aging of human marrow stromal cells following in vitro expansion. Stem cells; 2004, 22: 675-682. Ref.: https://goo.gl/NkyjX5

16. Fotia C, Massa A, Boriani F, Baldini N, Granchi D. Hypoxia enhances proliferation and stemness of human adipose-derived mesenchymal stem cells. Cytotechnology. 2015; 67: 1073-1084. Ref.: https://goo.gl/4S83eW

17. Hu X, Wu R, Shehadeh LA, Zhou Q, Jiang C, et al. Severe hypoxia exerts parallel and cell-specific regulation of gene expression and alternative splicing in human mesenchymal stem cells. BMC Genomics. 2014; 15: 303. Ref.: https://goo.gl/eeWm6r

18. Drela K, Sarnowska A, Siedlecka P, Szablowska-Gadomska I, Wielgos M, et al. Low oxygen atmosphere facilitates proliferation and maintains undifferentiated state of umbilical cord mesenchymal stem cells in an hypoxia inducible factor-dependent manner. Cytotherapy. 2014; 16: 881-892. Ref.: https://goo.gl/TxD3bj

19. Wong TY, Chang $\mathrm{CH}, \mathrm{Yu} \mathrm{CH}$, Huang LLH. Hyaluronan keeps mesenchymal stem cells quiescent and maintains the differentiation potential over time. Aging Cell. 2017; 16: 451-460. Ref.: https://goo.gl/nKCRW6

20. Xiong Y, He J, Zhang W, Zhou G, Cao Y, et al. Retention of the stemness of mouse adipose-derived stem cells by their expansion on human bone marrow stromal cell-derived extracellular matrix. Tissue Eng Part A. 2015; 21: 1886-1894. Ref.: https://goo.gl/ZFqUVb

21. Cesarz Z, Tamama K. Spheroid Culture of Mesenchymal Stem Cells. Stem Cells Int. 2016; 2016 9176357. Ref.: https://goo.gl/VREHiz

22. Obara C, Tomiyama K, Takizawa K, Islam R, Yasuda T, et al. Characteristics of three-dimensional prospectively isolated mouse bone marrow mesenchymal stem/stromal cell aggregates on nanoculture plates. Cell Tissue Res. 2016; 366: 113-127. Ref.: https://goo.gl/ua3pxP

23. Coutu DL, François M, Galipeau J. Inhibition of cellular senescence by developmentally regulated FGF receptors in mesenchymal stem cells. Blood. 2011; 117: 6801-6812. Ref.: https://goo.gl/fGd7Bo

24. Yu Y, Wei N, Stanford C, Schmidt T, Hong L. In vitro effects of RU486 on proliferation and differentiation capabilities of human bone marrow mesenchymal stromal cells. Steroids. 2012; 77: 132-137. Ref.: https://goo.gl/itVMJN

25. Kubo H, Shimizu M, Taya $Y$, Kawamoto $T$, Michida $M$, et al. Identification of mesenchymal stem cell (MSC)-transcription factors by microarray and knockdown analyses, and signature moleculemarked MSC in bone marrow by immunohistochemistry. Genes Cells. 2009; 14: 407-424. Ref.: https://goo.gl/VVpfQW

26. Yuan Z, Zhang J, Huang Y, Zhang Y, Liu W, et al. NRF2 overexpression in mesenchymal stem cells induces stem-cell marker expression and enhances osteoblastic differentiation. Biochem Biophys Res Commun. 2017; 491: 228-235. Ref.: https://goo.gl/dPcdpe

27. Yu KR, Yang SR, Jung JW, Kim H, Ko K, et al. CD49f enhances multipotency and maintains stemness through the direct regulation of OCT4 and SOX2. Stem Cells. 2012; 30: 876-887. Ref.: https://goo.gl/cqznoZ

28. Fan Z, Yamaza T, Lee JS, Yu J, Wang S, et al. BCOR regulates mesenchymal stem cell function by epigenetic mechanisms. Nat Cell Biol. 2009; 11: 1002-1009. Ref.: https://goo.gl/a7XFKk 